\title{
PERILAKU POLITIK ( GOLPUT) DALAM KEHIDUPAN MASYARAKAT BANJAR
}

\author{
Endang Astuti \\ Email: 2010128220009@ulm.ac.id \\ Program Studi Pendidikan IPS Fakultas Keguruan dan Ilmu Pendidikan \\ Universitas Lambung Mangkurat \\ Banjarmasin
}

\begin{abstract}
Abstrak
Politik merupakan sebuah ilmu pengetahuan yang mengenai tentang katatanegaraan, dan juga politik ialah suatu aktivitas atau cara bertindak dalam mengahadapii sebuah permasalahan dengann adanya kebijakan politik, politik juga meruppakan suatu hubungan untuk mempengaruhi aksi-aksi dan kebijakan dari suatu pemerintah atau juga menyangkut suatu proses dalam menentukan tujuan sehingga dapat melakanakan tuuan tersebut. Adapun di dalam politik memiliki prilaku politik, didalam masyarakat didaerah banjar perilaku politik ini sering terjadi pada saat adanya sebuah pemilu atau pemilihan kadidat dalam suatu organisasi atau juga pada saat pemilihan gubernur, adapn golputt juga sebagai prilaku politik, masyaraakat sangat penting dalamm sebuah sistem demokrasi.
\end{abstract}

Keyword: politik, prilaku politik, pembelajaran politik

\section{PENDAHULUAN}

Politik merupakan suatu ilmu pengetahuan yang mengenai tentang adanya ketatanegaraan, dan juga politik ialah sebuah aktivitas atau cara bertindak dalam menghadapi sebuah permasalahan dengan adanya beberapa kebijakan politik, politik juga merupakan suatu hubungan untuk mempengaruhi aksi-aksi dan kebijakan dari suatu pemerintah atau juga menyangkut suatu proses dalam menentukan tujuan sehingga dapat melaksanakan tujuan itu. Politik di dalam kehidupan masyarakaat sangatlah penting, karena masyarakat akan terlibat langsung dengan adanya politik ini, apabila suatu politik terdapat didalam kehidupan masyarakat 
banjar maka masyarakat didaerah banjar akan ber- demokratis di tingkat lokal. Ilmu politik juga ialah suatu pembedahan dengan suatu konsep serta suatu filosofi tertentu, di praktekan mengunakan suatu tata cara persoalan, dan analisis tentang pengorganisasian di sesuatu negeri yang bertujuan buat rakyat yang dapat hidup makmur dan senang. Sesuatu negeri yang berdemokrasi, terdapat hak- hak ialah hak kemerdekaan pers, hak melaporkan suara, hak dalam beragama, hak berorganisasi. Yang mana kebebasan yang sama tiap warganegara, dan terdapatnya pengakuan terhadap suatu nilai- nilai serta martabat sebagai individu. Karena pembelajaran wajib di upaya mendidik manusia biar tumbuh serta warga terdapat biasanya tidak mengenali dan menguasai hak serta kewajiban mereka selaku kewarganegaraan. Perihal tersebut akibatnyakurangnya pembelajaran politik terhadap warga sendiri kurang begitu mengerti mengenaai pembelajaran poolitik semacam ini.

\section{HASIL DAN PEMBAHASAAN}

\section{PEMBELAJARAN POLITIK}

Pendidikan politik dapat dimaknai sebagai suatu usaha yang terencana, dengan sadar buat memberikan penyadaran kepada masyarakat yang sudah berhak memilah. Tujuan pendidikan politik yang palinng berarti ialah dapat membentuk uraian warganegaraa mendukung dan berfungsinya sistem pemerintahan secara sehat. Pendidikan politik ialah sesuatu usaha sadar unuk mengubah proses sosialisasi politik sehingga mereka pahamm dan menghayati nilai- nilai yang tercantum dalam suatu sistem politik yang sempurna. Dalam suatu filosofi pendidikan, belajjar meerupakan suattu proses panjang seumur hidup. Yang artinya yakni pendidikan politik perlu dilaksanakan secara berkesinambungan biar masyarakat dapat terus tingkatkan penjelasan nya terhadap dunia politik yang tetap hadapi perkembangan. Manfaat pendidikaan politik dapat melatih warganegara biar meningkat partisiapasi politiknya. Proses pembelajaran politik semacam ini melalui suatu proses pembelajaran semacam adanya mata pelajaran PKN di ruang lingkup sekolah dasar. Dan kala seorang anak beranjak berumur dan mempunyai zona bermain baru buat dirinya. Tidak cuma itu, media masa pula yakni salah satu yang berperan berarti dala penyaluran pendidikan politik. 
Pendidikan politik ini sangat bermanfaat untuk warga sebab pendidikan politik yang baik akann menghilakan dari rasa tidak keyakinan terhadap sesuatu piihan yang hendak di seleksi buat mengarah perihal yang lebih baik. Pembelajaran politik pula ialah suatu proses dalam penanaman nilai- niai politik yang dicoba dengan terencana serta terencana yang mempunyai watak resmi ataupun informal yang mana dicoba secara terus menerus dari generasi ke generasi, supaya warganegara bisa berpartisipasi dalam politik, dan mempunyai pemahaman hendak suatu hak serta kewajiban supaya bisa bertanggung jawab. Belajar ialah suah proses dalam mencari ilmu buat masa depan serta proses belajar iini ialah seumur hidup, serta bahwsanya pembelajaran politik ialah suatu uraian terhadap dunia politik yang senantiasa hadapi pertumbuhan. Serta dalam suatu pembelajaran politik ini mengaitkan seluruh kalangan dari kalangan muda sampai kalangan tua, Sebab pembelajaran politik wajib diawali dari saat ini.

\section{GOLPUT SEBAGAI PRILAKU POLITIK}

Perilaku politik merupakan sebuah aktivitas yang berhubungan langsung dengan proses politik, baik dalam pembuatan keputusan politik sampai kepada pelaksanaan aktivitas politik secara periode. Didalam masyrakat di daerah banjar perialku po itik ini sering terjadi pada saat adanya, pemilu atau pemilihan kadidat dalam suatu organisasi atau juga pada saat ( pemilihan Gubernur ), adapaun golput juga sebagai perilaku, perilaku politik masyarakat menjadi suatu unsur penting dalam sebuah sistem demokrasi. Yang mana demmokrasi merupakan suatu sistem berupa sisstem dari rakyat oleh rakyatt dan untuuk rakyat. Demokrasi dikatakan berhasil apabila tingkat partisipasimasyaraakat dalam tatanegaraan dan pemerintahan tinggi, begitulah sebaliknya. Masyarakat yang golput merupakan suatu hal yang selalu ada di setiap pemilu, ada tiga teori yang menjelaaskan fenoomena golput tersebut yaitu ang pertama, teori sossiologis yang mana seseorang tidak ikut dalam pemilihan akibat dari latar belakang sosiologis. Misalnya faktor agama, pendidikan, perkerjaan, ras, daan sebagainya. Kedua, teori psikologis. Keputusan seseorang untuk ikut memilih atau tidak di tentukan oleh faktor psikologis seperti pendekataan dengan partai atau kadidat yang ada. Ketiga, teori ekonomi politik yang mana keputussan untuk memilih atau tidak di landasi oleh pertimbangan rasional, seperti ketidakpercyaan dengan pemilihan yang membawa perubahan ebih baik, tau bisa juga ketidakpercayaan akan adanya 
suatu perubahhan dan sebagainya. Golput dalam pemilu ialah wujud perlawanan atas ketidak berdayaan masyrakat terhadap pemerintahan, golput ini ialah sesuatu wujud kritik warga terhadap pemerintahan yang masih terjebak dalam demokrasi prosedural. Demokrasi prsedural alam padangannya merupakan arti demokrasi yang berakhir sehabis terdapatnya parpol, pemilu, legislatif, ataupun prosedur yang lain, sepanjang kesejahteraan belum di miliki oleh rakyat serta sepanjang itu pula golput hendak senantiasa terdapat.

\section{BEBERAPA FAKTOR TERJADINYA GOLPUT}

Pertama rakyat akan terjadi distrust secara politik kepada seorang calon kadidat yang akan maju untuk menjadi seorang calon pemimpin. Selain itu masyarakat yang memilih dan tidak memilih ialah merupakan sebuah tindakan yang sadar dalam pemilu, tetapi apabila golput dalam pemilihan suara itu karena kurangannya kepercayaan terhadap seseorang yang menjadi kadidat, yangg mana apabila calon kadidat memiliki prilaku yang buruk atau juga terkena banyak kasus jjelas akan dapat mempersulitt untuk adanya seseorang dalam memilih, karena pemilihan tersebut di lakukan rakyat, golput dilakukann oleh seseorang pemiilih, ialah sebuah

prootes warga serta keputusan warga dengan terdapatnya janji- janji yang tidak sempat di realisasikan sehingga rakyat juga terlanjur pesimis, serta pula memburuknya citra elit poolitik dengan terdapatnya aplikasi korupsi semangkin membuat seseorang partisipasi pemilih hendak menyusut serta sudah mencederai hati seorang pemilih tersebut. Ke- tiga, ialah dimana minimnya data tentang terdapatnya pilkada yang mana juga di sebabkan kurangnya tentang terdapatnya pemilu, tidak hanya itu pula sang pemilih tidak tahu dengan wujud yang di pilihnya ataupun yang hendak dipilihnya, oleh karena itu dalam pemilihan pilkada tersebut di perlukannya penebaran serta atribut- atribut yang lain yang hendak mengajak pemilih supaya berminat menggunnakan hak seleksi serta hak politiknya tersebut. Serta pula menyusun dan melaksanakan sosialisasi supaya bisa menguatkan suatu partisipasi pemilih. Tidak hanya itu pula membuat kampanye- kampanye pencerahan kepada rakyat supaya bisa memakai hak seleksi wajib dicoba secara komprehensif. 
Ke- 4 yakni adanya suatu upayaa daripihak tertentu yang di terencana maupun tidak disengaja yang sifatnya menghalangi maupun pula membuat seseorang sulit maupun tidak dapat mengenakan hak pilihnya. Di mana upaya menghalangi, ini biasanya dicoba oleh salah satu pihak maupun suatuu kelompok pendukung dari calon pemimpin, upaya semacam ini umumnya membatasi seorang buat memilah dan sudah mencederai arti dari demokrasi, masyarakat negeri yang baik juga pula memberikan suaranya ataupun memakai hak piihnya dalam memilah seorang calon pimpinannya. Dengan demikian untuk calon pemimpin serta elite politik supaya bisa membetulkan citranya secara positif pada suatu publik, sehiingga masyaraakat akaan bisa berempati serta pula hirau dalaam memakai hak suaranya tersebut. Sebab tiap ssebuah opsi sangat lah berharga dalaam suatu kegiatan dalam pemilu.

\section{Kesimpulan}

politik merupakan suatu ilmu pengetahuan yang mengenai tentang adanya ketatanegaraan dan juga politik ialah sebuah aktivitasatau cara bertindak dalam menghadapi sebuah permasalahan dengan adanya beberapa kebijakan politik politik juga merupakan suatu hubungan untuk mempengaruhi aksi-aksi dan kebijakan dari suatu pemerintahan yang mana juga menyangkut suatu proses dalam menentukan tujuan sehingga dapat melaksanakan tujuan tersebut. Pembelajaran politik ini ialah suatu usahasadar buat mengganti prooses sosialisasi politik warga sehingga mereka bisa pahami serta menghayati betul- betul dalam nilai yang tercantum dalam sesuatu sistem politik yang hendak dibentuk. perkawinan politik ini pula ialah suatu proses dalam penanamann nilai- nilai politik yang dicoba dengan terencana serta terencana supaya mempunyai watak resmi ataupun informal yang mana dicoba secara selalu dari generasi ke generasi buat masyarakat negeri bisa berpartisipasi dalam politik dan mempunyai pemahaman hendak suatu hak serta kewajiban dan bertanggung jawab.

Masyarakatyang memilih golput merupakan suatu hal yang selalu ada di setiap pemilu ada tiga teori yang menjelaskan tentang fenomena golput tersebut.masyarakat yang memilih dan tidak memilih ialah merupakan sebuah tindakan yang sadar dalam pemilu tetapi apabila golput dalam pemilihan suara itu karena kurangnya kepercayaan terhadap seseorang dalam yang menjadi kandidat pemilu tersebut.apabila calon kandidat memiliki perilaku yang buruk atau juga terkena banyak kasus jelas akan dapat mempersulit adanya seseorang dalam memilih karena pemilihan tersebut dicoba oleh rakyat. golput dicoba oleh seseorang pemilih sebab itu ialah suatu wujud 
keluhan warga serta keputusan warga dengan terdapatnya janji- janji yang tidak sempat direalisasikan serta rakyat juga telanjur pesimis serta pula buruknya Citra elit politik terdapatnya aplikasi korupsi terus menjadi membuat seorang partisipasi pemilih hendak menyusut serta sudah mencederai hati seorang pemilih tersebut.

\section{DAFTAR PUSTAKA}

Abdullah,A.A, dan Suhartini,s. (2017) meningkatkan kemapuan brpikir kritis melalui pemebelajaran statistika berbasis pendidikan politik di lingkungan sekolah. Jurnal gantamg $2(1), 1-9$

Ramlansurbakti, Memahamii ilmu politik, jakarta:Grasindo.1999 hal130

Yanuarti,s (2016), Golput dan pemilu di indonesia. Jurnal penelitian politik, 6(1),21-32

Syaharuddin, S., Rahman, A. M., \& Fitriyani, R. (2019). Utilization Of Social Community as Learning Resources On Social Studies. The Kalimantan Social Studies Journal, 1(1), 18-24. 